\title{
Sensopatic Games for the Early Childhood Sensory Integration Special Program
}

\author{
Sri Joeda Andajani, Siti Latifah \\ Department of Special Education \\ Universitas Negeri Surabaya \\ Surabaya, Indonesia \\ sriandajani@unesa.ac.id
}

\begin{abstract}
The purpose of this study was to examine the validity and practicality product of specific program of sensory integration through sensopatic games for early age children with total visual impairment. This development research uses a 4D model design from Thiagarajan. Besides, the results of specific program sensory integration through sensopatic games for early age children with total visual impairment contain product specifications such as, 1) sensopatic game equipment accompanied by two Braille dice, 2) printed gamebook in the form of mold and braille, 3) authentic assessment tool for measuring success in sensopatic games. Result this study: it shows that the product specific program sensory integration through sensopatic games for visual impairment children can be used as an effort to help facilitate learning in understanding sensory integration in the kindergarten environment.
\end{abstract}

Keywords—specific program; sensory integration; sensopatic

\section{INTRODUCTION}

The visual barriers of children with visual impairments in early childhood is an inability to understand sensory and intelligence [1]. In this case, visual stimulus experience is needed In order to develop reconnaissance abilities for children with visual impairments at an early age. The most difficult thing for children with total visual impairment in early stage is when they playing age. Generally, the learning stages of early age children begin with a variety of experiences through play. This stage is a provision to improve the concept of a new learning environment. However, this is different for children with total blindness at an early age who are hampered in their experience and are likely not to experience the stages of play.

Recent evidence from a number of sources indicates that visually impaired students access and succeed in almost all higher education curriculum areas as defined by the Higher Education Statistics Agency [2]. Providing good quality activities in daily life that is done by teachers and parents can affect the growth of visual impairment children. Thus, the mobility assistance is needed as a way to prepare independence in everyday life. A number of individual activities may be successfully learned by the visual impairment student that afford him an opportunity to experience a great deal of physical mobility and independence and achieve rather remarkable success [3].
This means that for early age children with total visual impairment, direct physical experience is important for the welfare of their lives.

Based on the observation result in 2018, at Special Kindergarten YPAB Surabaya the data that is obtained from early age children with total visual impairment has minimal sensory integration capabilities that are suitable for their age. In the Kindergarten curriculum for learning programs, the specifics guidance for visual impairment children still cannot be fully implemented yet. The condition of visual impairment children in existence requires help in moving because they tend to be a passive student in the classroom during learning activities. Another difficulty experienced by visual impairment children at 4-7 years old is the minimum of vocabulary they have. So, that it affected to their speaking ability. Furthermore, there are some of the students who still cannot speak yet even though they don't have a problem with their speech organs.

In connection with early age, the stage of children age is to explore the environment and get various experiences as a provision for their lives. The excessive fear of early age children with total visual impairment is caused by not getting used to being trained to know the environment. In the other hand, being passive in doing activity becomes one of the factors that can inhibit motor development [4]. Developing games is one of the activities that can represent various experiences and an alternative in introducing the environment for children with total visual impairments. They do have limitations on visual abilities, but there are no obstacles in developing their cognitive, motoric and physical abilities. These things are the basis that in fact children with total visual impairment are able to explore many things in playing activities and doing various useful experiments as their experience. Besides, playing is part of children world that is really fun for them. Therefore, no wonder that most of the time is spent for playing [5].

Sensopatic game is a choice of game for early age children with total visual impairment. The introduction of various kinds of different texture objects to be touched should be done by involving direct interaction of children. Giving imagination and stimulation to early age children with total visual impairment showed that the body can adjust when touching objects that are soft, hard, rough, soft and 
smooth. The Object requirements in sensopatic game should be 1) prickly, 2) rough and smooth, 3) downy, 4) wrinkled and humped, and 5) writhing. Sensopatic game is a play activity that involves sensory functions through touch which is continued in the information center to process an impression and understanding of the stimulus [6].

Every young child with visual impairments needs the opportunity to get to know the sense of touch. The hearing experience is less effective without touch, which is to feel the difference sensation directly [7]. Sensation is an energy that stimulates or activates nerve cells and involves sensory organs and peripheral nervous system (periphere), but not all sensations must be accepted and translated as sensations that have meaning, so that the information is received or not depending on the reception of the channel transmission, the efficiency of the reception center in the brain, the relationship of the center of various sensory channels, and the ability of the central coding and sensation to provide meaningful interpretation [8].

The power of sensation through various senses cannot be measured, even though the differences in sensation can be determined. Experience with engaging the physic directly will help to develop the concept of own perception of the shape and nature of objects and create experiences that can be understood by visual impairment children at an early age [9]. Sensopatic game is useful for practicing tactile sensibility in the process of the next step through touch like reading Braille. The maximum tactile capability will accelerate the process of learning the next stages such as independence, mobility, and cognitive development [10]. The touch of hands in this sensopatic game can be felt by the soles of the feet which are important body parts that are used in mobility which also become a problem for early age children with visual impairment.

Based on the problems above, this study aims to examine the validity and practicality product of sensory integration development program through sensopatic game for children with visual impairment at an early age. The product of specific program sensory integration is available in the basic competencies of specificity curriculum for visual impairment children in special kindergarten [11].

\section{METHOD}

The development model that is used in this study is the 4D model, the model used for the specific program of sensory integration through sensopatic game for early age children with total visual impairment. The stages of the 4-D development model are define, design, develop, and disseminate. But in this study, modifications are made through 3 stages of development these are: 1) define, 2) design, and 3) develop [12].

\section{RESUltS AND DISCUSSION}

First, The Product Result of Sensori Integration Specific Program through Sensopatic Games for early age student with total visual impairment. This part shows the results of validity and practicality which is obtained from the results of material content validation, design experts, and validation of classroom teacher user who teach early age children with total visual impairment at the Special Kindergarten In the assessment, instruments have been provided to provide advice and input from the product of the sensory integration specific program through sensopatic game for students with total visual impairment [13]. The assessment result from the material content validator, design validator and Special Kindergarten classroom teacher practitioners are listed below: (1) The Result of Content Product Validation of Sensori Integration Specific Program through Sensopatic Games for early age student with total visual impairment shows that Material content expert suggested on the preparation of sensopatic game parts, that are about miniatures as well as their original form of various crops and fruit seeds including the size of the display area that can provide an overview and explanation to visual impairment children. The miniature fruit displays and real fruit should be placed systematically, so that it makes the student easier to understand the whole texture of the sensopatic game. In a book overview of the accompanying program for specific sensory integration through sensopatic game for early age students with total visual impairment, it has the potential to provide a comprehensive understanding of the process until the end of the game. Giving authentic assessment in the game process is conducted in order to see student's understanding and ability to understand the rules in a sensopatic game. Below are the results of the content expert test results that is obtained through analysis of instrument assessment data. Based on validity criteria, it can be concluded that the results of content validation of the specific program product rise the score 58:13 $=4.461$. It means the development of sensory integration through sensopatic game for students with visual impairments is valid in term of content material. (2) Validation Result from Product Design Experts of Sensory Integration Specific Program through Sensopatic Games for Early Age Children with Total Visual Impairment shows that Design expert suggested on the preparation of sensopatic game part, that are about miniatures as well as their original form of various crops and fruit seeds including the size of the display area that can provide an overview and explanation to visual impairment children. The miniature fruit displays and real fruit should be placed systematically, so that it makes the student easier to understand the whole texture of the sensopatic game. In a book overview of the accompanying program for specific sensory integration through sensopatic game for early age students with total visual impairment should be written in braille and alert. It also has the potential to provide a comprehensive understanding of the process until the end of the game. Giving authentic assessment in the game process is conducted in order to see student's understanding and ability to understand the rules in a sensopatic game. The data analysis of product design validation instruments for the development program of sensory integration through the sensopatic game for early age children with visual impairment as. The validity results through data analysis then interpreted the results through a list of validity criteria. Based on the validity list criteria, it can be concluded that the results of the development 
program design validation obtained a score of 52:13 $=4$ which can be interpreted that the program of sensory integration through sensopatic game for total visual impairment students is in the valid category in terms of design. (3) The assessment result of Special Kindergarten practitioner / teacher shows that the assessment practitioner of suggested on the preparation of sensopatic game part, that are about miniatures as well as their original form of various crops and fruit seeds including the size of each display box that should be given braille writing. Different boxes that contains both miniature and original one with braille writing can provide an overview and explanation for children with visual impairments during learning process. The miniature fruit displays and real fruit should be placed systematically, so that it makes the student easier to understand the whole texture of the sensopatic game. In a book overview of the accompanying program for developing sensory integration through sensopatic game for early age students with total visual impairment should be written in braille and alert. It also has the potential to provide a comprehensive understanding of the process until the end of the game. Giving authentic assessment in the game process is conducted in order to see student's understanding and ability to understand the rules in a sensopatic game. The data analysis of the results of filling the practicality instrument practicality for the development program of sensory integration through the sensopatic game for early age children with visual impairment as. The practicality assessment through data analysis then interpreted the results through a list of validity criteria. Based on the assessment list, it can be concluded that the practicality results of the development program design validation obtained a score of 52: $13=4$ which can be interpreted that the program of sensory integration through sensopatic game for total visual impairment students is in the practical category in terms of practicality.

The result of this study indicated that the program for developing sensory integration through sensopatic game for early age children with visual impairments in Kindergarten who experience barriers in sensory integration abilities is feasible to be used. Below is the assessment result: (1) The result of content / material expert validation were 4.46 (valid), (2) The result of design expert validation were 4 (valid), (3) The results of a small-scale user assessment were 4,67 (practical).

This development program really needs the attention and cooperation from educators and parents to get the results of the learning process. The realization of this development program as a basic aspect in learning independence and developing the cognitive abilities of children with total visual impairments. The sensory of integration which is developed is intended as a stimulus through touch, smell, sound and taste. They are combined into one managed information, so that they discover and recognize new information about objects and their textures in the real sense. Thus, it is kind of an introduction of objects in direct experience, through touch, smell, sense of taste and hearing.

In the specific program of sensory integration through sensopatic games, this was created to realize the specific curriculum as a guideline for developing mobility, social and communication orientations that had not been done by Special Kindergarten teachers. This sensory of integration functions as a basic competency, specifically introducing various objects textures for visual impairment children in kindergarten at an early age. This game also familiarizes the total visual impairment children to get used to know the surrounding environment through touch, smell, taste, and sound that they hear. This program can develop the independence of children with total visual impairments, in order to be able to play a role in the community. The product from the sensory integration development program through sensopatic game is used to assist teachers in assisting and teaching total visual impairment children in Kindergarten [13].

Based on the data analysis result from products of sensory integration development programs for total visual impairment children, it can be seen that this developed program has been declared feasible by experts and practitioners. The validity of the presented content is in accordance with the physical, intellectual, emotional, social and spiritual level of development of children with total visual impairments.

The recommended program material is in accordance with the specialization development program as a guideline for developing mobility, social and communication orientations for visual impairment students, stating that children with total visual impairment at the age of 4-7 years should have sensory integration abilities in accordance with the developmental stages of their age. Children with visual impairment have the same responsibilities like the ordinary children; these are learning and practicing to become independent person. The results of the material content expert validator assessment that has been analyzed, states that the sensory integration development program for students with total visual impairment is considered as a feasible program to be applied by teachers in learning activity [14].

The design aspect of the integration sensory development program has received a feasible category by obtaining a score of 4 . It means that this program is feasible to be applied at the Special Kindergarten. Based on the validation result that has been assessed by the program design expert, the data analysis shows that the format, font size, grammar, sentence structure, color design, instructions and direction, space/layout arrangement and the assessment/evaluation system are complete, good and worthy to be applied. The suitability of learning methods in sensory integration development programs for students with total visual impairment use of the method depends on the suitability of the objectives, the material, the ability of the teacher, the condition of the students, facilities and infrastructure, the situation and conditions, and time [15].

According to the practicality assessment test states that practical products in games as well as the learning media that are used in sensory integration development programs for students with total visual impairment is in line with the objectives, material, methods, and evaluation. The media that 
is used in this development program has been adapted to the conditions and characteristics of students. In the learning process, methods and media are very important elements. These two elements are related each other because the determination of the method will affect the media used. On the learning media need to pay attention to the students, because the essence of each group of students has different characteristics. The Conformity of learning media with this specific purpose is a factor that determines success in a sensory integration program for early age children with total visual impairment [16].

\section{CONCLUSION}

Based on the data and the result of research specific program that has fulfilled the valid and practical criteria used by teachers in Special Kindergarten, it can be concluded with the two points: First, the average result of validation test that is done by material content specialist are 4.46 and design experts are 4.0. Second, The average result of practical test from Special Kindergarten class teacher users are 4.67.

\section{REFERENCES}

[1] M. Kingsley, "The Effect of Visual Loss, dalam Visual Impairment," GBR: David Fulton, Publisher, 1999.

[2] A. W. Roy, "Students with visual impairment," in Special teaching in higher education: Routledge, 2003, pp. 51-59.

[3] S. Hrisos, M. P. Clarke, T. Kelly, J. Henderson, and C. M. Wright, "Unilateral visual impairment and neurodevelopmental performance in preschool children," British journal of ophthalmology, vol. 90, no. 7, pp. 836-838, 2006

[4] G. A. Calvert and J. W. Lewis, "Hemodynamic studies of audiovisual interactions," in Handbook of multisensory processing: MIT press, 2003.

[5] M. Maguire, C. Nicolle, and M. Galley, "Review of state of knowledge regarding the safety, access and usability needs of children with disabilities," 2007.

[6] M. A. Gielen, "Play, toys and disabilities: the Bio-approach to designing play objects for children with various abilities," in Proceedings of the 4th International Toy Research Association world congress, 2005.

[7] E. Singer, "Play and playfulness, basic features of early childhood education," European Early Childhood Education Research Journal, vol. 21, no. 2, pp. 172-184, 2013.

[8] A. J. Ayres and Z. Mailloux, "Influence of sensory integration procedures on language development," American Journal of Occupational Therapy, vol. 35, no. 6, pp. 383-390, 1981.

[9] G. van den Broek, F. Cavallo, and C. Wehrmann, AALIANCE ambient assisted living roadmap. IOS press, 2010.

[10] N. F. Aldajani, "Exploration of the Effectiveness of Tactile Methods," Online Submission, 2016.

[11] W. T. A. ARE, "Special education: Contemporary perspectives for school professionals," 2005.

[12] S. Thiagarajan, "Instructional development for training teachers of exceptional children: A sourcebook," 1974.

[13] S. Niemann and N. Jacob, "Helping Children who are Blind," Hesperian Foundation: USA, 2000.

[14] S. M. Benner and J. Grim, Assessment of young children with special needs: A context-based approach. Routledge, 2012.

[15] S. Asra, "Metode Pembelajaran," Bandung: CV Wacana Prima, 2008.

[16] M. Rohman and S. Amri, "Strategi dan desain pengembangan sistem pembelajaran," Jakarta: Prestasi Pustakaraya, 2013. 